\title{
THE PERMANENT GOVERNMENT OF THE CANAL ZONE
}

\author{
By William P. Borland, Representative in Congress from \\ Missouri.
}

As the time approaches for the completion of the Panama Canal it becomes important to turn our attention to the problem of the permanent government of the little stretch of territory which is destined to play an important part in the future military and commercial history of the world.

The acquisition of the Zone and the construction of the canal have proceeded so rapidly that we have scarcely had time to consider the questions bearing upon permanent control and occupation. Thus far we have regarded the Zone as an immense construction camp under military discipline. The people on the Zone are mainly those whom we have brought or sent there for the purpose of constructing the canal; the work being done under the supervision of officers of the United States Army; and the purpose to be accomplished, the digging of the canal with the greatest possible expedition, efficiency and economy. When the construction days are over, however, a form of government adapted to such temporary conditions must give way to something of a permanent nature. The views of public men on the question of a permanent government will differ according to their ideas of the paramount purpose of the canal. One view will be dominated by the idea that the canal is primarily a military necessity, the other view, by the thought that its highest purpose is the promotion of peace and commerce.

The plan to construct an inter-oceanic canal at, or near, the Isthmus of Panama first assumed importance during the gold rush to California in I849. The result was the Clayton-Bulwer Treaty of 1850 between Great Britain and the United States. This treaty contemplated that such a canal would be constructed, probably in Nicaragua or Costa Rica, and that the work would be undertaken by a private company organized under the authority of one or the other of the signatory powers. The controlling motive of this treaty was clearly commercial: it expressly restrained each nation from fortifying the canal or from occupy- 
ing, colonizing or exercising sovereignty over any country through which the canal might be constructed, and it was contemplated that other civilized states should be invited to join in the treaty for the protection and neutralization of the canal.

No canal was begun under this treaty. Meanwhile, American capitalists had constructed the Panama Railroad, which proved a very valuable property. Later a French company, headed by the celebrated engineer, Compt de Lesseps, secured a concession from the government of Colombia for the construction of a commercial canal across the Isthmus. This canal was actually begun and nearly $80,000,000$ cubic yards of excavation made. The failure and subsequent bankruptcy of this company was due to causes partly natural and partly administrative. The thousands of French stockholders lost their money and after a legal receivership, the concessions and property, including the Panama Railroad, passed into the hands of a small band of speculators who acquired the property for a song, with the design of selling it to the United States Government.

In I9or, after the war with 'Spain, the United States sought and obtained from Great Britain a new convention known as the Hay-Pauncefote treaty, which superseded the Clayton-Bulwer agreement. This treaty provides that an inter-oceanic canal shall be constructed entirely by the government of the United States, or by private corporations with its aid; that the basis of the neutralization of the canal shall be the rules adopted for the free navigation of the Suez Canal, and that no change of territorial sovereignty or of the international relations of the country, or countries, traversed by the canal shall affect the general principle of neutralization. This treaty omits all mention of fortifications. From this omission it is assumed that our government regained the right to fortify the canal at the expense of agreeing with Great Britain to waive the terms of the Clayton-Bulwer Treaty. In other words, Great Britain has conceded to us the right to construct a canal entirely at our own expense and to fortify it as we please, provided that we never charge her ships more than we charge our own, and that we allow her at all times free use of the canal facilities on the same terms as ourselves. As Great Britain has the largest merchant marine in the world, equal to the combined merchant marine of several other countries, it is manifest that as a commercial proposition she will make $\$$ ro profit out of the construction of the canal to our $\$ \mathrm{I}$, and this 
without any expense to her in either constructing, policing or protecting the canal. She is quite satisfied that we should restrict our use of the canal to military purposes, so long as we are bound by treaty to accord her every commercial advantage.

The next step.in the construction of the canal was the passage of the so-called Spooner Act of January 28, I902. By this act the President was given power to acquire the property of the new Panama Canal Company, or the alternative of constructing a canal through Costa Rica or Nicaragua. He was empowered to appoint a commission to be charged with the duty of constructing the canal. It is a matter of common history that the negotiations following this act led to a revolution by which the State of Panama seceded from the Republic of Colombia and entered into a treaty with the United States which cleared the way for the acquisition by the United States of the property of the new Panama Canal Company. This treaty between the United States and Panama was proclaimed February 26, I904, and is the basis of all of the present rights of the United States in the Canal Zone.

The Second Article of the treaty provides:

"The Republic of Panama grants to the United States in perpetuity the use, occupation and control of a zone of land and land under water for the construction, maintenance, operation, sanitation and protection of said canal of the width of ten miles extending to the distance of five miles on each side of the center line of the route of the canal to be constructed ;"****

By this article a grant is made by the Republic of Panama of all right, title and interest it has in the land embraced in the strip, containing approximately 400 square miles, extending from the Caribbean Sea to the Pacific Ocean. It seems to be intended, and has been construed, to be a grant of the full title to all public land claimed by the Republic of Panama within the Zone. This question was squarely decided in Wilson $v$. Shaw, 204 U. S., page 33 , in which case suit was brought to restrain the officers of the United States from expending money in the construction of the canal on the ground, among others, that the United States did not own the land upon which the canal was being constructed. On this point Justice Brewer, in delivering the opinion of the Court, said,

" "It is hypercritical to contend that the title of the United States is imiperfect, and that the territory described does not belong to 
this Nation, because of the omission of some of the technical terms used in ordinary conveyances of real estate."

By the Sixth Article of the treaty the Republic of Panama grants to the United States the right to acquire by purchase or eminent domain any lands, or other property, within the cities of Colon and Panama, which may be considered necessary for canal purposes. By the Eighth Article of the treaty the Republic of Panama grants to the United States all reversionary interest which it may have as successor to the Republic of Colombia in the property and franchises of the new Panama Canal Company. This treaty, having resulted, as was contemplated by both parties. in the purchase by the United States of the property of the new Panama Canal Company, has made the United States the proprietor not only of all the public land within the Canal Zone but of all the private property of the new Panama Canal Company in the Zone and in the cities of Panama and Colon, and the reversionary interest of the Republic of Panama in all the land and other property of the new Panama Canal Company. The Federal government claims therefore, that it now owns the fee title to the public land in the Canal Zone together with several valuable pieces of real estate in the City of Panama and nearly all the real estate in the City of Colon. The City of Colon is built almost entirely upon land, the ownership of which was in the new Panama Canal Company, and which is leased to the persons constructing and occupying the buildings. The United States, since the acquisition of this property, has still further improved it by the construction of new docks, warehouses, terminals and other facilities.

The United States has further enlarged its holdings of real estate within the Canal Zone by extinguishing through the power of eminent domain the private titles in such portions of the land as are taken or damaged by the construction of the canal and the filling of the lake. None of the real estate acquired by the United States has been sold. A system of leasing has been adopted under the authority of an Act of Congreess, approved February II, I909. By this act the President is authorized to grant leases of public lands in the Canal Zone, not needed for actual use by the canal, for a period not exceeding twenty-five years, and in tracts not exceeding fifty hectares. The terms and conditions of the lease were left to the discretion of the President, but the lessee must be the head of a family, over twenty-one years 
of age, and the lease must be made in good faith for the purpose of actual settlement and cultivation.

So much for the position of this government as a proprietor. Its powers as a sovereign are defined by Article Three of the treaty as follows:

"The Republic of Panama grants to the United States all the rights, power and authority within the zone mentioned and described in Article 2 of this agreement and within the limits of all auxiliary lands and waters mentioned and described in said Article 2 which the United States would possess and exercise if it were the sovereign of the territory within which said lands and waters are located to the entire exclusion of the exercise by the Republic of Panama of any such sovereign rights, power or authority."

It may be noticed that this article does not confer actual sovereignty upon the United States, but provides that this government shall possess all the rights, power and authority within the zone as if it were sovereign of the territory to the entire exclusion of the exercise by the Republic of Panama of any such power or authority. This wording is as obscure as the wording of Article 2, by which the grant of land is made to this government. In Article 2, the Republic of Panama grants to the United States - "In perpeuity the use, occupation and control of a zone of land." Justice Brewer properly decided that such a grant necessarily carried the fee title, as it entirely excluded the rights, present or reversionary, of any other proprietor. He well stated that the absence of technical words of conveyance could not alter the nature of the title. The same reasoning should apply to the right of sovereignty in Section 3 of the treaty. If the United States has all the rights, power and authority within the zone which it could possess and exercise if it were sovereign of the territory, and it is to exercise these powers to the entire exclusion of the emjoyment by the Republic of Panama of any such rights, power or authority, it is manifest that there is but one sovereign over the zone and that is the United States. It occupies therefore, with relation to the Canal Zone, the same position that it occupies with relation to the Louisiana Purchase, Alaska, or any other added territory. By the treaty its powers of sovereignty are expressly extended beyond the limits of the Canal Zone for certain purposes. In Section 7,-

"The Republic of Panama agrees that the cities of Panama and Colon shall comply in perpetuity with the sanitary ordinances, 
whether of a preventive or curative character, prescribed by the United States, and in "case the Government of Panama is unable or fails in its duty to enforce this compliance by the cities of Panama and Colon with the sanitary ordinances of the United States, the Republic of Panama grants to the United States the right and authority to enforce same.

"The same right and authority are granted to the United States for the maintenance of public order in the cities of Panama and Colon and the territories and harbors adjacent thereto in case the Republic of Panama should not be, in the judgment of the United States, able to maintain such order."

Following the ratification of the treaty with Panama an act was passed, approved April 28, 1904, to provide for the temporary government of the Canal Zone. Section 2 of this act, follows:-

"That until the expiration of the Fifty-eighth Congress, unless provision for the temporary government of the Canal Zone be sooner made by Congress, all the military, civil and judicial powers, as well as the power to make all rules and regulations necessary for the government of the Canal Zone and all the rights, powers and authority granted by the terms of said treaty to the United States shall be vested in such person or persons and shall be exercised in such manner as the President shall direct for the government of said zone and maintaining and protecting the inhabitants thereof in the free enjoyment of their liberty, property and religion."

This act, which remains substantially unchanged, contains the whole law for the civil government of the zone. It seems to have been assumed that the powers of civil government were vested in the Canal Commission. In fact the President, on May 9, I904, issued a letter of instructions to the Secretary of War outlining a plan for such civil government. The Canal Commission has been created and had formulated a complete civil government for the Canal Zone, including courts, police, fire and sanitary regulations, fees and licenses, schools, public works, and other necessary branches. The commission originally acted as the legislative body of the zone. Between August 16, 1904, and March I, I905, the commission enacted a number of laws which are published in book form and numbered from I to 24 inclusive. After that time this method of legislation was abandoned and no other acts (or ordinances, as they are called), of the commission have been passed. General legislation has been enacted from time to time under the form of executive orders signed and promulgated by the President. These executive orders relate to 
every possible phase of civil life and cover every known branch of legislation from the qualifications to practice a profession to the procedure for the administration of an estate. In the aggregate they form a large and undigested mass of legislation, in the main fragmentary acts torn from the statute books of various states, which govern in the points expressly covered the conduct and rights of the persons within the zone. As to matters not covered by any specific executive order, the law applicable to rights of individuals is extremely hazy. It seems to be assumed, in accordance with the settled principles of private international law, that where one country acquires sovereignty over a territory which has enjoyed a system of local laws established by a civilized government, the local laws shall continue to prevail until they are supplanted by express legislation of the new sovereign. According to this principle there is a vague and ill defined body of laws supposed to have been in force under the Colombian government and to have remained in force after the revolution establishing the independence of Panama. This body of laws, as in the case in all Latin American countries, is an evolution from the civil or Roman law. Unfortunately this body of laws is a sealed book to the judge sitting in the American courts of the Canal Zone. So far as I am aware few of the judges on that bench have been able to read the Spanish language or have had any knowledge through experience or study of the Colombian law. In but one instance, so far as I know, has it been appealed to as the basis of a decision in the American courts. In a recent case it was decided that a person injured on the Panama Railroad by the negligence of its employees had no right of action against the railroad company because under the principles of the Colombian law the employer is not legally responsible for the negligence of his employee.

This chaotic condition of the law and of private rights is emphasized by two decisions of the Supreme Court of the United States. In the case of Coulson v. the Government of the Canal Zone, 212 U. S., page 553, it was decided that a writ of error to review a judgment of the Supreme Court of the Canal Zone must be dismissed for want of jurisdiction. No written opinion was filed but the effect of this decision is that the judgiment of the Supreme Court of the Canal Zone is final in all cases and there is no power of review in the Supreme Court of the United States or any other tribunal. Another phase of the same question was 
presented in the case of Kaufman v. Smith, 206 U. S., 6Io, in which the Supreme Court of the United States held: "The questions involved in this case as to the right of the government to collect duties on merchandise coming into the United States from the Canal Zone, under the Act of March 2, Ig05, have already been settled by the case of Downes v. Bidzell, I82 U. S., 244, and the writ of error is dismissed for want of jurisdiction." Downes $v$. Bidwell is the celebrated case in which the Supreme Court of the United States decided that the Constitution did not extend to the Island of Porto Rico. The Supreme Court therefore holds, in accordance with that case, that the Constitution of the United States does not extend to the Canal Zone.

By a gradual but very natural encroachment all of the power, legislative, executive and even judicial, within the Canal Zone has been transferred to and absorbed by the chairman and chief engineer of the Canal Commission. I say judicial, not only because there have been no cases in the zone courts against either the commission or the railroad company, but that have been promptly reversed by the Supreme Court of the Canal Zone, but because I have seen a copy of a letter from the chairman and chief engineer of the Canal Commission to one of the judges of the Circuit Court refusing to recognize the authority of a receiver of private property appointed by a decree of said court. In other words, we have in the zone a complete and perfect type of a benevolent despotism. A benevolent despotism may work very satisfactorily for a short time amid the enthusiasm of a great scientific work which calls out all that is best in the patriotism and professional ambition of men, and especially where the benevolent despot is drawn from, and centers upon himself the public sentiment, of $93,000,000$ people who have been trained by a century and a half of self government. After the enthusiasm of the construction work is over, however, and public attention is diverted to other matters it is perfectly manifest that such a system of government would be the worst possible, not only for the governed but also for the governors, and especially for the public.

At this time, as we approach the completion of the project and its practical operation, we must choose between the only two systems of administration that will be possible. If the canal is regarded as primarily a military enterprise, with only such commercial advantages as are incidental, then the government might be purely military and placed under the arbitrary control of a 
military governor accountable only to the President. This seems to be the view of the present chairman and chief engineer of the Isthmian Canal Commission. As a logical result he advises that the entire zone should be cleared of inhabitants when the canal is completed, except the employees engaged in its operation and soldiers quartered there for defense. Of course, he believes that a large number of soldiers should be maintained there, together with fortifications and land batteries sufficient not only to repel an attack by sea but to withstand any possible invading force that might approach by land. The entire zone is to be made a military reservation, which would necessitate the acquisition by the United States of the title to all the private land which it does not now own. The United States now owns, according to the highest claim, about 60 per cent of the land in the zone, so that to turn the zone into a military reservation it would be necessary to acquire the remaining 40 per cent. Under the treaty with Panama the value of private land acquired by the United States in the zone must be fixed by a joint commission appointed by the government of the United States and the government of Panama, composed equally of Americans and citizens of Panama. Only one such commission, known as the Denby Commission, has been appointed during the life of the treaty. This commission awarded to private owners prices below what they claimed but greatly in excess of what the United States officers contended were reasonable. The result is that the chairman and chief engineer of the commission is strongly opposed to any further joint commission under the treaty, and has followed the plan of seizing the lands necessary to be used and leaving the private owner to litigate as long as he chooses. Under any plan, however, it is apparent that the acquisition of the remaining 40 per cent of the land within the zone would be made at enormous expense: To further emphasize his views, the chairman contends that the presence of a producing and trading population on the zone would greatly impair its military strength and even hints that it might introduce an element of danger; further that the land itself is worthless for the purpose of cultivation. It may be said that these views are not shared by other military members of the commission.

I am frank to say that after three visits to the zone and a fairly careful study of its commercial and physical characteristics, I am entirely opposed to the military reservation theory. The land is not remarkably good, but it will produce in paying quantities all 
of the tropical products, including bananas, oranges, lemons, limes, grape fruit, mango, casaba, guava, cocoanut, chocolate bean, coffee, pine-apples and rubber. The principal drawback of the tropics is not the unproductiveness of the soil, but the difficulties of transportation and the unhealthfulness of the climate. The land within the zone enjoys a very fortunate situation both as regards transportation and sanitation. It will have the most remarkable transportation facilities of any tropical district in the world, and I believe that every foot of available land would be eagerly taken up by our American employees as fast as the construction force is disbanded. In fact our employees are now going just beyond the edge of the zone into the Republic of Panaama and investing their money in tracts of land there, with the intention of remaining. If a force of white Americans can be induced to live in the zone along the route of the canal, even though they employed largely Jamaica negro labor in operating their plantations, it would not be a menace but might be an aid to the protection, repair and operation of the canal.

Again, it is inevitable that warehouses and other business establishments of great shipping centers will spring up at each end of the canal. By the peculiar terms of the treaty with Panama the cities of Colon and Panama, while geographically within the zone, are excluded from American jurisdiction. From this it results that the limits of these cities are carefully defined and are completely surrounded by American territory. Hence, the growth of these cities, resulting from an overflow of their commercial population, must be upon American territory. To one who is used to commercial affairs and who has made an actual personal observation of conditions at both ends of the canal, it is almost inconceivable that the military occupation theory can be carried out in practice. It would leave absolutely no room for the cities to expand except by sufferance, which, in plain English, means by favoritism towards those who could secure locations upon the military reservation.

When the canal is completed a vessel entering from the Caribbean Sea will proceed about eight miles on a sea level to the foot of the Gatun Dam. At this point it will be raised by a flight of three locks to the level of the lake. The lake will be 165 square miles in extent, dotted with beautiful islands and surrounded by the luxuriant verdure of the tropics. A sail of twenty-three miles across the lake will bring the vessel to the entrance of the 
cut at Bas Obispo. From thence there will be more than nine miles of narrow canal through the Calebra Cut to Pedro Miguel, where by means of one lock the vessel is lowered to the little lake of Miraflores. At this point two more locks permit the vessel to reach ocean level on the Pacific, from whence a journey of seven miles brings it out to the Bay of Panama at Balboa. The time consumed in this trip would enable the passengers to cross the Isthmus by railroad and reach Panama several hours ahead of the ship to transact business or to entertain and amuse themselves. The trip will be a very beautiful one, especially in the dry season of early winter, and the zone may easily become one of the most delightful winter resorts in the world. It may be dotted from end to end with beautiful hotels equipped with American conveniences, surrounded by spreading verandas and shaded by stately groves of palms. Every amusement would be within the reach of the winter guest: horse-back riding, canoeing, golf, tennis, sailing, surf bathing, deep sea fishing, and numerous exploring trips to neighboring islands.

But above and beyond all this in the minds of most Americans, that great mass of our-citizens whose money has paid for the construction of this great work, is the thought that the supreme importance of the canal consists in the fact that it will open up new channels of trade to American commerce. If we can count on the friendship and trade of our South American neighbors and turn to our own shores some of the wealth that is flowing year by year to Europe, we shall perhaps regain manyfold the enormous cost of the canal. This means that the canal ports will soon be - busy with American commerce, crowded with American merchants and rapidly building up with American warehouses and branches of American commercial establishments. It is hardly to be conceived that we should handcuff ourselves through the medium of a military reservation and turn the best commercial advantages of the canal over to England, Germany and our other commercial rivals.

It may be said that it will be difficult to frame and enforce a suitable government for such a territory with such a population. Conceding the difficulty, are we to assume that the only solution is to drive the population off at the point of a bayonet? Every foot of land in the Canal Zone not actually needed for the operation of the canal should be sold, not leased, but sold in fee to American citizens. Preference should be given to the employees 
of the canal. As to government, the form should first be that of a territory, with a governor appointed by the President, but without a legislative assembly. One United States Court should be established, with the usual provision for review by a Circuit Court of Appeals and by the Supreme Court of the United States. Legislation should be enacted for the zone by Congress in the same manner that legislation is now enacted for the District of Columbia. It has long been the desire of American lawyers to secure, under national authority, a complete codification of the laws of this country, especially upon commercial subjects. Commendable efforts have been made by the American Bar Association to secure uniform state laws upon commercial paper, bills of lading, etc. Here is an opportunity for both practical and experimental legislation that may well challenge the attention of the American Bar Association. When England acquired India, a vast country of petty sovereignties, with a decayed civilization, she found it necessary to enact codes of laws on commercial subjects for the use of the British subjects who were developing India commercially: hence the English Contract Act, the English Evidence Act, etc. No such opportunity has been before presented to our country to codify and enact under the authority of Congress an advanced and complete commercial code for the use of American citizens. It is a subject worthy of the thought of the entire Bar. Such a code applicable to Panama could be made a model for the commercial codes of each of the forty-eight States and would have its influence upon the commercial life of the entire world: It would establish an uniform system of commercial rights which would bring us into touch with all of our. neighboring countries and form the basis of an international code of commerce. Such an international code is the great need of the present day and the biggest contribution that the legal profession can at this time make to the advancement of civilization.

Wm. P. Borland. 